\title{
Absenteeism and Associated Factors in Workers of a High-Level Educational Institution, Cartagena-Colombia
}

\author{
Carolina Castaño ${ }^{1}$, Regina Dominguez ${ }^{2}$, Rocio Romero ${ }^{1}$, Diana Saldarriaga ${ }^{1} \&$ Raimundo Castro-Orozco ${ }^{3}$ \\ ${ }^{1}$ Human Movement and Health Research Group, Grupo de Investigación Movimiento Humano y Salud-GIMHUS, \\ Universidad de San Buenaventura, Cartagena, Colombia \\ ${ }^{2}$ Health and Social Practices Research Group, Grupo de Investigación en Salud y Prácticas Sociales-SYPRES, \\ Universidad de San Buenaventura, Cartagena, Colombia \\ ${ }^{3}$ Group of Biomedical Research, Grupo de Investigaciones Biomédicas-GIB, Universidad de San Buenaventura, \\ Cartagena, Colombia \\ Correspondence: Raimundo Castro-Orozco, Universidad de San Buenaventura, Calle Real de Ternera No. 30-966 \\ - PBX 653 5555, Cartagena, Colombia. E-mail: raimundo_castro_orozco@hotmail.com
}

Received: August 13, 2018 Accepted: October 5, 2018 Online Published: November 27, 2018

doi:10.5539/gjhs.v10n12p136

URL: https://doi.org/10.5539/gjhs.v10n12p136

\begin{abstract}
To analyze the sociodemographic characteristics, organizational factors and cardiovascular risk factors related to work absenteeism in a higher education institution in the city of Cartagena-Colombia. Cross-sectional analytical study with a probabilistic sample of 162 workers. We recorded sociodemographic data, personal and family history, in addition, we performed a physical examination that included: abdominal circumference, height, weight and blood pressure. Also, clinical laboratory tests were performed for the analysis of lipid profile (total cholesterol, HDL cholesterol and triglycerides) and fasting blood glucose, determined by enzymatic colorimetric and automated methods. A frequency of absenteeism of $24.7 \%$ was estimated, being more frequent in the age group of 40 to 49 years and with a statistically significant difference between women and men. All the organizational variables studied showed a statistical association with work absenteeism. In contrast, the only cardiovascular risk factors that showed statistical association were: abdominal obesity and personal history of arterial hypertension. The evidences found allow us to think about the need to implement, immediately, a program of lifestyle change and healthy work, which includes a motivational strategy of change that, together, reduce the occurrence of absenteeism and the prevalence of cardiovascular risk factors found in the study population.
\end{abstract}

Keywords: absenteeism, sick leave, education, higher, physical activity

\section{Introduction}

Work absenteeism, defined as the absence of an employee to his workplace for reasons of illness or accident, excluding vacations, strikes, pregnancy or prison (Gomero, Murguia, Calizaya, Mejia, \& Sanchez, 2018), is considered a multifactorial phenomenon with capacity to affect companies, workers and the general economy of a country (Rabarison, Lang, Bish, Bird, \& Massoudi, 2017).

Generally, factors associated with work absenteeism could be classified into two categories, those related to health and sociodemographic characteristics of the employee and organizational factors, such as: seniority, type of hiring, salary, position, workday, satisfaction, among others (Barmby, Ercolani, \& Treble, 2002; Dionne \& Dostie, 2007).

Consequently, there are reports indicating that with the implementation of programs that promote worker health and wellbeing, the occurrence of absenteeism is reduced and the productivity of the company is increased (Rabarison et al., 2017).

In context of worker health, it is worth noting the reported relationship between the increase in absenteeism due to illness and cardiovascular risk factors. Among these are: obesity, physical inactivity, hypertension, smoking, diabetes mellitus and dyslipidemia (Gomero et al., 2018; Losina, Yang, Deshpande, Katz, \& Collins, 2017; Zarate, 2009). Moreover, the elimination of a cardiovascular risk factor from a worker's profile could reduce more than $2.0 \%$ of the occurrence of absenteeism (Pelletier, Boles, \& Lynch, 2004).

However, there are discordant reports that indicate the independence of these risk factors with the frequency of 
absenteeism due to illness in various groups of workers (Castillo Rascón et al., 2016; Howard \& Potter, 2014).

The objective of this study was to analyze sociodemographic characteristics, organizational factors and cardiovascular risk factors, related to work absenteeism in a higher education institution in the city of Cartagena-Colombia.

\section{Methods}

An analytical cross-sectional study was carried out, with a probabilistic sample of 162 workers of both sexes, belonging to the positions of teachers, operators and administrative staff of a higher education institution in the city of Cartagena-Colombia. All individuals linked as workers were included, who consented to their participation in the study. We excluded those workers who had reported heart disease, trauma with evolution less than two months or acute respiratory compromise.

The sociodemographic data of each individual, personal and family background were recorded and a physical examination was performed, which included the abdominal circumference by using a perimetric tape (II \& SB) with pressure control and blood pressure. Size was recorded with digital tallimeter calibrated in centimeters (II \& $\mathrm{SB}$, range between $40-600 \mathrm{~cm}$ ) and weight was measured with Tanita ${ }^{\circledR}$ floor scale (model BC552, Continental Scale Corp., Bridgeview, III, USA) with resolution $0.100 \mathrm{~kg}$. Also, clinical laboratory tests were performed for the analysis of the lipid profile (total cholesterol, HDL cholesterol and triglycerides) and fasting glycemia, determined by enzymatic colorimetric and automated methods (HumaStar 100, Human Diagnostic, USA).

The parameters established by the American Heart Association (AHA) were used to determine the presence of cardiovascular risk factors, which included: waist circumference $>40$ inches in men and $>35$ inches in women; triglyceride levels $>150 \mathrm{mg} / \mathrm{dL}$; HDL cholesterol $<40 \mathrm{mg} / \mathrm{dL}$ for men and $<50 \mathrm{mg} / \mathrm{dL}$ in women; diastolic and systolic blood pressure $>130 / 80 \mathrm{mmHg}$, respectively, and fasting blood glucose levels $>100 \mathrm{mg} / \mathrm{dL}$ (Kramer, 2015).

The level of physical activity was evaluated using the abbreviated version of the International Physical Activity Questionnaire (IPAQ). For the assessment of absenteeism, we had access to the database of the absenteeism registry of the Human Management Unit of the institution of interest and we identified those absences due to medical disability.

Regarding the data analysis plan, the categorical variables were expressed in proportions and in their respective $95 \%$ confidence intervals. For the numerical variables, the measures of central tendency and dispersion were estimated according to the result of the goodness-of-fit test (Shapiro-Wilk test). The Chi-square test of independence was used to identify the statistical associations between variables and, according to the selected cross-sectional design, the prevalence ratio (PR) was estimated. To establish statistically significant differences between two independent groups, we interpreted the $95 \%$ confidence intervals of the difference (CI95\% ${ }_{\text {diff }}$ ) between the measures of central tendency used. The estimated p-values were interpreted avoiding the fallacy of statistical significance (Sterne \& Smith, 2001), with their respective effect size (Gaskin \& Happell, 2014).

All these procedures were performed with the statistical programs IBM ${ }^{\circledR}$ SPSS ${ }^{\circledR}$ Statistics version 23.0 (IBM Corp, Armonk, New York), GraphPad PRISM ${ }^{\circledR}$ version 6.01 (GraphPad software, San Diego, CA), EpiDat 3.1® (General Directorate of Innovation and Xestión da Saúde Pública, Xunta de Galicia, Spain, Pan American Health Organization and Higher Institute of Medical Sciences of Havana).

\subsection{Ethical Considerations}

According to Resolution No. 8430 of 1993 of the Ministry of Health of Colombia-Article 11, this study corresponded to a research with minimum risk, as it was prospective in nature and the data was recorded through common procedures. This study was reviewed and approved by the Bioethics Committee of the University of San Buenaventura-Cartagena.

\section{Results}

In this study 162 workers from a private university of the Colombian Caribbean Coast were evaluated, with a predominance of females $(108 / 162,66.7 \%$, CI95\% $59.1 \%$ to $73.5 \%)$ and with a median for the age of 40 years (IQR : 32.8 to 47.0 ). The median time of service and seniority of this population corresponded to 6 years (IQR: 2.0 to 13.3 ) and 7 years (IQR: 2.8 to 16.0 ), respectively.

The majority of the population under study $(120 / 162,74.1 \%$, CI95\% $66.8 \%$ to $80.2 \%)$ belonged to the first three socioeconomic strata and with a technical, university or higher educational level $(91.4 \%, 148 / 162$, CI95\% 86.0 \% to $94.8 \%)$. 
In this study population, a frequency of absenteeism from work was estimated at $24.7 \%(40 / 162, \mathrm{CI} 95 \% 18.7 \%$ to $31.9 \%$ ), and a record of multiple absenteeism of $27.5 \%(11 / 40$, CI95\% $16.1 \%$ to $42.8 \%$ ), with a median absence of work of three times during the period evaluated (IQR: 2 to 4 times), being more frequent the occurrence of absenteeism in the age group of 40 to 49 years $(37.5 \%, 15 / 40$ CI95\% $24.2 \%$ to $53.0 \%)$.

Table 1 shows the statistical associations found between work absenteeism and study variables. Regarding the sociodemographic characteristics, we found statistical evidence of a weak association between the socioeconomic stratum and the sex of the worker with the occurrence of work absenteeism. In addition to this, a statistically significant difference was found between women and men in relation to the occurrence of work absenteeism (CI $95 \%{ }_{\text {diff }} 12.3 \%$ to $\left.34.9 \%\right)$.

All the organizational variables studied showed a statistical association with work absenteeism. The prevalence of work absenteeism among workers with a position of workers was approximately 3.3 times higher compared to the prevalence estimated in teachers ( $\mathrm{PR}=3.3, \mathrm{CI} 95 \% 1.6$ to 7.2$)$. Something similar was found in the comparison of the prevalences of labor absenteeism estimated in workers with administrative position and teachers $(\mathrm{PR}=2.3$, CI95\% 1.1 to 4.7). Added to this, a moderate statistical association was found between the current position of worker and absenteeism.

Although there is evidence of a weak statistical association between work absenteeism and the type of contract of the worker evaluated, accompanied by a statistically significant difference between the frequencies of work absenteeism estimated in workers with an indefinite term contract and a fixed-term contract $\left(\mathrm{CI} 95 \%{ }_{\text {diff }} 3.5 \%\right.$ to $30.2 \%)$.

The weak statistical association found between the absenteeism of work and the time of service of the evaluated worker, was accompanied by the statistically significant difference detected between the median for the time of service among workers with record of absenteeism of those without this type of registration (CI95\% $\%_{\text {diff }} 1.0$ to 5.0 years; $\mathrm{p}=0.006$ ).

The only cardiovascular risk factors that showed statistical association with the occurrence of work absenteeism in the evaluated population were: abdominal obesity and personal history of arterial hypertension. In both situations a weak association was found, additionally, it was estimated that the prevalence of absenteeism in workers with abdominal obesity was approximately 1.8 times higher compared to the estimated prevalence in workers without this risk factor ( $\mathrm{PR}=1.8 \mathrm{CI} 95 \% 1.0$ to 3.5 ). Something similar was found with the personal history of arterial hypertension ( $\mathrm{PR}=2.1, \mathrm{CI} 95 \% 1.1$ to 3.9 ).

Physical activity with vigorous / moderate intensity was weakly associated with the occurrence of absenteeism (p $=0.064, \mathrm{Phi}=0.2)$, but no difference between the estimated prevalence ratios among workers with vigorous/ moderate intensity compared to those with high intensity. mild physical activity $(\mathrm{PR}=0.6, \mathrm{ICI} 95 \% 0.3$ to 1.1$)$.

Table 1. Sociodemographic characteristics, organizational factors, and cardiovascular risk factors related to employee absenteeism in Colombian higher education institution, 2017

\begin{tabular}{lllll}
\hline Study variables & $\begin{array}{l}\text { Absenteeism } \\
\text { Yes (n=40) }\end{array}$ & $\begin{array}{l}\text { Absenteeism } \\
\text { No (n=122) }\end{array}$ & p-value & Effect size \\
\hline Age (years) & 42 (IQR: 37 to 48) & 39 (IQR: 25 to 75) & 0.289 & \\
\hline Sex & 5 & 49 & 0.001 & Phi=0.3 \\
Male & 35 & 73 & & \\
Female & & & & \\
\hline Marital status & 7 & 35 & & \\
Single & 15 & 52 & & \\
Married & 5 & 6 & & \\
Divorced & 1 & 4 & & \\
Widow(er) & 10 & 18 & & \\
Consensual union & & & & \\
\hline
\end{tabular}




\begin{tabular}{|c|c|c|c|c|}
\hline Socioeconomic status & & & & \\
\hline Low & 34 & 86 & \multirow{3}{*}{0.062} & \multirow{3}{*}{$\mathrm{Phi}=0.3$} \\
\hline Medium & 2 & 26 & & \\
\hline High & 4 & 10 & & \\
\hline \multicolumn{5}{|l|}{ Work type job } \\
\hline Teachers & 9 & 60 & \multirow{3}{*}{0.006} & \multirow{3}{*}{ Phi $=0.4$} \\
\hline Administrative support workers & 21 & 49 & & \\
\hline Operatives & 10 & 13 & & \\
\hline Seniority (years) & 8 (IQR: 5 to 15 ) & 4 (IQR: 2 to 13 ) & 0.006 & Rosenthal $\mathrm{r}=0.2$ \\
\hline \multicolumn{5}{|l|}{ Types of contracts } \\
\hline Fixed-term & 15 & 72 & \multirow{2}{*}{0.013} & \multirow{2}{*}{ Phi $=0.2$} \\
\hline Undefined-term & 25 & 48 & & \\
\hline \multicolumn{5}{|l|}{ CRF } \\
\hline Hyperglycemia & 2 & 4 & \multicolumn{2}{|l|}{0.986} \\
\hline Hypercholesterolemia & 4 & 12 & \multicolumn{2}{|l|}{0.783} \\
\hline Low HDL cholesterol & 7 & 23 & \multicolumn{2}{|l|}{0.887} \\
\hline Hypertriglyceridemia & 9 & 28 & \multicolumn{2}{|l|}{0.953} \\
\hline \multicolumn{5}{|l|}{ BMI } \\
\hline Normal weight & 10 & 48 & \multirow{3}{*}{0.135} & \\
\hline Overweight & 22 & 58 & & \\
\hline Obese & 8 & 13 & & \\
\hline \multicolumn{5}{|l|}{ Waist circumference } \\
\hline Normal & 10 & 51 & \multirow{2}{*}{0.05} & \multirow{2}{*}{ Phi $=0.2$} \\
\hline High & 30 & 70 & & \\
\hline \multicolumn{5}{|l|}{ Level of physical activity } \\
\hline Light & 30 & 71 & \multirow{2}{*}{0.07} & \multirow{2}{*}{ Phi $=0.2$} \\
\hline Moderate/vigorous & 10 & 50 & & \\
\hline Personal history of HTA & 7 & 8 & 0.04 & \multirow{2}{*}{$\mathrm{Phi}=0.2$} \\
\hline High blood pressure & 3 & 23 & 0.10 & \\
\hline
\end{tabular}

IQR: interquartile range; CRF: cardiovascular risk factor; BMI: body mass index; HTA: hypertension.

\section{Discussion}

The importance of the economic costs generated by absenteeism due to medical reasons is recognized, in terms of loss of productivity and quality of work (Asfaw, 2014; Bankert, 2015).

This study reports a lower frequency of work absenteeism than those published in other Colombian populations, such as metal-mechanic industry workers (Agredo Zúñiga et al., 2013), agroindustrial sector workers (Arias-Moreno, Carvajal, \& Cruz, 2015), in administrative and assistance staff of a forensic institution (Escobar-Aramburo et al., 2015), in workers of the operating area of a mineral extraction company (Vásquez Trespalacios, 2013) and in operators of a public mass transport company (Mosquera Navarro, Ordoñez Cubides, \& Grajales, 2016), but it is higher than the frequency reported in workers of a Health Promoting Company (Martinez-Lopez \& Saldarriaga-Franco, 2008).

Among the possible explanations for the disparity observed in the behavior of the occurrence of absenteeism in the various groups of workers mentioned above, are: (I) underreporting of reports of medical disability or other types of absenteeism, as a consequence of a poor system of management (Stock et al., 2014); (II) the culture of absence 
in the company, (III) different expectations of the worker and (IV) the multifactorial characteristic of labor absenteeism (Sanchez, 2013; Vásquez Trespalacios, 2013).

The frequency of work absenteeism estimated in this study was higher in women than in men, which is the result of the evidence obtained in predictive studies (Barmby et al., 2002; Dionne \& Dostie, 2007). In part, this behavior could be explained by the different social obligations assigned to these individuals (Barmby et al., 2002).

As for the organizational factors, in the group of workers with the hiring of an indefinite term, an occurrence of higher absenteeism was estimated than workers with a fixed-term contract, with more than three percentage points of difference between them. Several authors state that the type of contracting establishes the highest or lowest degree of commitment, satisfaction and welfare related to work absenteeism. In other words, from the perception of the worker, he considers that the elderly with a fixed charge (Coluccio Piñones, 2016; Sanz, 2017).

In coherence with the results found, some investigations show that excess weight is one of the risk factors with greater predominance in the other types (Agredo Zúñiga et al., 2013; Manzano \& López Hernández, 2017; Orozco-González, Cortés- Sanabria, Viera-Franco, Ramírez-Márquez, \& Cueto-Manzano, 2016; Puescas Sánchez, Cabrera Enríquez, \& Díaz Vélez, 2012).

On the other hand, no statistical association could be found between the occurrence of work absenteeism and the cardiovascular risk factors studied, except for the personal history of hypertension, since the prevalence of absenteeism was approximately two times higher in workers with a personal history. Of hypertension compared to those who did not present this type of personal history.

Other investigations give support to these results with their findings (Castillo Rascón et al., 2016; Ruiz de la Fuente Tirado et al., 1992), which indicate a higher frequency of absenteeism due to illness in hypertensive workers compared to normotensive. Moreover, since the 1980s, hypertension has been recognized as one of the determinants of work absenteeism (Sexton \& Schumann, 1985).

Obesity in workers affects their production capacity and daily performance (Rodbard, Fox, \& Grandy, 2009), resulting in high direct and indirect costs for the company (Højgaard, Olsen, Søgaard, Sørensen, \& Gyrd-Hansen, 2008), so much so that it is considered that the annual costs derived from medical expenses and absenteeism in obese workers reach up to 45 billion dollars (Klonoff, 2009).

There is evidence that indicates that abdominal obesity acts as an independent predictor of work absenteeism, unlike obesity determined by body mass index (Moreau et al., 2004), but even this is discordance (Jans, van den Heuvel, Hildebrandt, \& Bongers, 2007).

Also was found a weak association between absenteeism and abdominal obesity in the population of workers evaluated. This statistical relationship has been previously reported in Colombian workers (Agredo Zúñiga et al., 2013) and in European workers (Fitzgerald, Kirby, Murphy, \& Geaney, 2016; Korpela et al., 2013; Moreau et al., 2004).

Within this context, five possible conceptual models of interaction between obesity, exposure at the workplace and illness have been stated: (I) obesity can modify the causal relationship between occupational exposure and a specific illness; (II) obesity and occupational exposure act as independent risk factors, but additives for the development of a specific disease; (III) work as a source of adverse environmental exposures and promoter of obesity, which in combination or independently can modify the risk of occurrence of a specific disease; (IV) occupational exposure can modify the causal relationship between obesity and a certain disease and (V) obesity and occupational exposure can trigger two different diseases, which can interact (Schulte et al., 2007).

Some of these conceptual models can be supported by evidence indicating that the behavior over time of abdominal obesity can be influenced by the application of job enrichment as a motivational strategy for change (Fried et al., 2013).

In this group of workers, no relationship was found between absenteeism and other cardiovascular risk factors, such as hypercholesterolemia and obesity, similar to that reported in public employees (Castillo Rascón et al., 2016), but different from that reported by other authors (Leynen et al., 2006).

In relation to the evaluation of physical activity through the IPAQ, no differences were observed between the prevalence of work absenteeism estimated between the two categories of intensity of physical activity studied (vigorous / moderate vs. mild). Mild physical activity has been negatively associated with absenteeism, only when accompanied by the consumption of a diet of high nutritional quality (Fitzgerald et al., 2016).

It is important to highlight the proven impact of lifestyle programs and healthy work, of immediate application, in terms of a sustained reduction in the worker's body weight and certain cardiovascular risk factors (Dallam \& Foust, 
2013; Daubert, Ferko-Adams, Rheinheimer, \& Brecht, 2012; Kramer, 2015).

Beyond the limitations derived from the cross-sectional design used, the evidences found in this probabilistic test for workers imply the need to implement, immediately, a lifestyle and healthy work change program that fits a motivational strategy change, such as the enrichment of the job, but recognizing the different barriers to participation related to work, for the reduction of working time, the occurrence of work absenteeism and the prevalence of cardiovascular risk factors found in the study population .

\section{Acknowledgements}

We thank Colciencias for financing the research (announcement 706 of 2015, code of agreement CB4012016). Likewise, we thank the board of directors of the Universidad de San Buenaventura-Cartagena for their support and collaboration (code: C0053).

\section{Competing Interests Statement}

The authors declare that there are no competing or potential conflicts of interest.

\section{References}

Agredo Zú-iga, R. A., García Ordo-ez, E. S., Osorio, C., Escudero, N., López-Albán, C. A., \& Ramírez-Vélez, R. (2013). Obesidad abdominal y ausentismo por causa médica en una empresa de la industria metalmecánica en Cali, Colombia. Revista Peruana de Medicina Experimental y Salud Publica, 30, 251-255.

Arias-Moreno, P., Carvajal, R., \& Cruz, Á. M. (2015). Ausentismo en Trabajadores con Reintegro Laboral. 2015, $2(4), 5$.

Asfaw, A. G., Chang-Chia, C.; Ray-Tapas, K. (2014). Workplace mistreatment and sickness absenteeism from work: Results from the 2010 National Health Interview survey. American Journal of Industrial Medicine, 57(2), 202-213. https://doi.org/10.1002/ajim.22273

Bankert, B. C. C., Pope, J. E., \& Wells, A. (2015). Regional Economic Activity and Absenteeism: A New Approach to Estimating the Indirect Costs of Employee Productivity Loss. Population Health Management, 18(1), 47-53. https://doi.org/10.1089/pop.2014.0025

Barmby, T. A., Ercolani, M. G., \& Treble, J. G. (2002). Sickness absence: an international comparison. The Economic Journal, 112(480), F315-F331. https://doi.org/10.1111/1468-0297.00046

Castillo Rascón, M. S., Castro Olivera, C., Sánchez, A., Ceballos, B. H., Pianesi, M. E., Malarczuk, C., . . . Sánchez, A. (2016). Ausentismo laboral y factores de riesgo cardiovascular en empleados públicos hospitalarios. Acta Bioquímica Clínica Latinoamericana, 50(1), 37-44.

Coluccio Pi-ones, Á., \& Mu-oz Calderon, C., \& Ferrer Urbina, R. (2016). Situación contractual y su relación con satisfacción laboral, clima organizacional y absentismo en docentes. Salud \& Sociedad, 7(1), 98-111. https://doi.org/10.22199/S07187475.2016.0001.00006

Dallam, G. M., \& Foust, C. P. (2013). A Comparative Approach to Using the Diabetes Prevention Program to Reduce Diabetes Risk in a Worksite Setting. Health Promotion Practice, 14(2), 199-204. https://doi.org/10.1177/1524839912437786

Daubert, H., Ferko-Adams, D., Rheinheimer, D., \& Brecht, C. (2012). Metabolic Risk Factor Reduction Through A Worksite Health Campaign: A Case Study Design. Online Journal of Public Health Informatics, 4(2), ojphi.v4i2.4005. https://doi.org/10.5210/ojphi.v4i2.4005

Dionne, G., \& Dostie, B. (2007). New Evidence on the Determinants of Absenteeism Using Linked Employer-Employee Data. ILR Review, 61(1), 108-120. https://doi.org/10.1177/001979390706100106

Escobar-Aramburo, M. F., Duarte-Suárez, M. L., Caicedo-Campo, L. L., García, M. M., Valderrama-Aguirre, A., \& Cruz, A. M. (2015). Ausentismo Laboral por Enfermedad de Origen Infeccioso en una Institución Forense. Revista Colombiana de Salud Ocupacional, 3(2), 6.

Fitzgerald, S., Kirby, A., Murphy, A., \& Geaney, F. (2016). Obesity, diet quality and absenteeism in a working population. Public Health Nutrition, 19(18), 3287-3295. https://doi.org/10.1017/S1368980016001269

Fried, Y., Laurence, G. A., Shirom, A., Melamed, S., Toker, S., Berliner, S., \& Shapira, I. (2013). The relationship between job enrichment and abdominal obesity: A longitudinal field study of apparently healthy individuals. Journal of Occupational Health Psychology, 18(4), 458-468. https://doi.org/10.1037/a0033730

Gaskin, C. J., \& Happell, B. (2014). Power, effects, confidence, and significance: An investigation of statistical 
practices in nursing research. International Journal of Nursing Studies, 51(5), 795-806. https://doi.org/10.1016/j.ijnurstu.2013.09.014

Gomero, R., Murguia, L., Calizaya, L., Mejia, C. R., \& Sanchez, B. A. (2018). Association between the Increase in Body Mass Index and Medical Absenteeism in a Peruvian Mining Population. Int J Occup Environ Med, 9(3), 129-136. https://doi.org/10.15171/ijoem.2018.1201

Højgaard, B., Olsen, K. R., Søgaard, J., Sørensen, T. I. A., \& Gyrd-Hansen, D. (2008). Economic Costs of Abdominal Obesity. Obesity Facts, 1(3), 146-154. https://doi.org/10.1159/000137822

Howard, J. T., \& Potter, L. B. (2014). An assessment of the relationships between overweight, obesity, related chronic health conditions and worker absenteeism. Obesity Research \& Clinical Practice, 8(1), e1-e15. https://doi.org/10.1016/j.orcp.2012.09.002

Jans, M. P., van den Heuvel, S. G., Hildebrandt, V. H., \& Bongers, P. M. (2007). Overweight and Obesity as Predictors of Absenteeism in the Working Population of the Netherlands. Journal of Occupational and Environmental Medicine, 49(9), 975-980. https://doi.org/10.1097/JOM.0b013e31814b2eb7

Klonoff, D. C. (2009). A Sweetened Beverage Tax is Needed to Combat the Obesity Epidemic as Well as Related Absenteeism and Presenteeism. Journal of Diabetes Science and Technology, 3(3), 408-410. https://doi.org/10.1177/193229680900300301

Korpela, K., Roos, E., Lallukka, T., Rahkonen, O., Lahelma, E., \& Laaksonen, M. (2013). Different measures of body weight as predictors of sickness absence. Scandinavian Journal of Public Health, 41(1), 25-31. https://doi.org/10.1177/1403494812468965

Kramer, M. M. D., Arena, V., Venditti, E., Meehan, R., Miller, R., Vanderwood, K., ... \& Kriska, A. M. (2015). Improving Employee Health: Evaluation of a Worksite Lifestyle Change Program to Decrease Risk Factors for Diabetes and Cardiovascular Disease. Journal of occupational and environmental medicine/American College of Occupational and Environmental Medicine, 57(3), 284-291. https://doi.org/10.1097/JOM.0000000000000350

Leynen, F., Backer, G. D., Pelfrene, E., Clays, E., Kittel, F., Moreau, M., \& Kornitzer, M. (2006). Increased absenteeism from work among aware and treated hypertensive and hypercholesterolaemic patients. European Journal of Cardiovascular Prevention \& Rehabilitation, 13(2), 261-267. https://doi.org/10.1097/01.hjr.0000194420.62379.de

Losina, E., Yang, H. Y., Deshpande, B. R., Katz, J. N., \& Collins, J. E. (2017). Physical activity and unplanned illness-related work absenteeism: Data from an employee wellness program. PLOS ONE, 12(5), e0176872. https://doi.org/10.1371/journal.pone.0176872

Manzano, E. A., \& López Hernández, E. (2017). Relación del sobrepeso y obesidad con el rendimiento laboral en trabajadores de una empresa metalmecánica en México. Revista Colombiana de Salud Ocupacional, 6(4), 6.

Martinez-Lopez, E., \& Saldarriaga-Franco, J. (2008). [Sedentariness and absenteeism in the work setting]. Rev Salud Publica (Bogota), 10(2), 227-238. https://doi.org/10.1590/S0124-00642008000200003

Moreau, M., Valente, F., Mak, R., Pelfrene, E., de Smet, P., De Backer, G., \& Kornitzer, M. (2004). Obesity, body fat distribution and incidence of sick leave in the Belgian workforce: the Belstress study. International Journal of Obesity, 28, 574. https://doi.org/10.1038/sj.ijo.0802600

Mosquera Navarro, R., Ordo-ez Cubides, D., \& Grajales, A. C. (2016). Ausentismo Laboral por Motivos de Salud en Operadores de una Empresa de Buses del Sistema de Transporte Masivo de Cali, Colombia. 2016, 5(4), 8.

Orozco-González, C. N., Cortés-Sanabria, L., Viera-Franco, J. J., Ramírez-Márquez, J. J., \& Cueto-Manzano, A. M. (2016). Prevalencia de factores de riesgo cardiovascular en trabajadores de la salud. Revista Médica del Instituto Mexicano del Seguro Social, 54(5), 594-601.

Pelletier, B., Boles, M., \& Lynch, W. (2004). Change in Health Risks and Work Productivity Over Time. Journal of $\begin{array}{llll}\text { Occupational } & \text { 7nd }\end{array}$ https://doi.org/10.1097/01.jom.0000131920.74668.e1

Puescas Sánchez, P., Cabrera Enríquez, J., \& Díaz Vélez, C. (2012). Factores de riesgo de enfermedad cardiovascular, un problema en trabajadores de la salud. Acta Médica Peruana, 29, 8-9.

Rabarison, K. M., Lang, J. E., Bish, C. L., Bird, M., \& Massoudi, M. S. (2017). A Simple Method to Estimate the Impact of a Workplace Wellness Program on Absenteeism Cost. Am J Health Promot, 31(5), 454-455. 
Rodbard, H. W., Fox, K. M., \& Grandy, S. (2009). Impact of Obesity on Work Productivity and Role Disability in Individuals with and at Risk for Diabetes Mellitus. American Journal of Health Promotion, 23(5), 353-360. https://doi.org/10.4278/ajhp.081010-QUAN-243

Ruiz de la Fuente Tirado, S., Cortina Greus, P., Alfonso Sanchez, J. L., Saiz Sanchez, C., Sabater Pons, A., Gonzalez Arraez, J. I., \& Cortes Vizcaino, C. (1992). Job absenteeism and arterial hypertension: results of a hypertension control program. Eur J Epidemiol, 8(5), 660-665. https://doi.org/10.1007/BF00145381

Sanchez, D. C. (2013). Ausentismo laboral: una visión desde la gestión de la seguridad y la salud en el trabajo. Revista Salud Bosque, 5(1), 43-54. https://doi.org/10.18270/rsb.v5i1.182

Sanz, A. G. (2017). Absentismo y tipología de la contratación laboral. (Administración y Dirección de Empresas), Universidad de Valladolid. Retrieved from http://uvadoc.uva.es/bitstream/10324/24255/1/TFG-N.671.pdf

Schulte, P. A., Wagner, G. R., Ostry, A., Blanciforti, L. A., Cutlip, R. G., Krajnak, K. M., . . Miller, D. B. (2007). Work, Obesity, and Occupational Safety and Health. American Journal of Public Health, 97(3), 428-436. https://doi.org/10.2105/AJPH.2006.086900

Sexton, M., \& Schumann, B. C. (1985). Sex, race, age, and hypertension as determinants of employee absenteeism. Am J Epidemiol, 122(2), 302-310. https://doi.org/10.1093/oxfordjournals.aje.a114102

Sterne, J. A. C., \& Smith, G. D. (2001). Sifting the evidence-what's wrong with significance tests? Physical Therapy, 81(8), 1464-1469. https://doi.org/10.1093/ptj/81.8.1464

Stock, S., Nicolakakis, N., Raïq, H., Messing, K., Lippel, K., \& Turcot, A. (2014). Underreporting Work Absences for Nontraumatic Work-Related Musculoskeletal Disorders to Workers' Compensation: Results of a 20072008 Survey of the Québec Working Population. American Journal of Public Health, 104(3), e94-e101. https://doi.org/10.2105/AJPH.2013.301562

Vásquez Trespalacios, E. M. (2013). Absentismo laboral por causa médica en trabajadores del área operativa de una compa-ía de extracción de minerales en Colombia, 2011. Medicina y Seguridad del Trabajo, 59, 93-101. https://doi.org/10.4321/S0465-546X2013000100006

Zarate, A. C., M., Maiz, A., Ravest, G., Pino, M. I., Valdivia, G., Moreno, M., \& Villarroel, L. (2009). Influencia de la obesidad en los costos en salud y en el ausentismo laboral de causa médica en una cohorte de trabajadores. Revista médica de Chile, 137, 337-344. https://doi.org/10.4067/S0034-98872009000300003

\section{Copyrights}

Copyright for this article is retained by the author(s), with first publication rights granted to the journal.

This is an open-access article distributed under the terms and conditions of the Creative Commons Attribution license (http://creativecommons.org/licenses/by/4.0/). 